\title{
MANAJEMEN PEMBELAJARAN MODEL BLOCK SYSTEM LEARNING PADA PENDIDIKAN TINGGI VOKASI DI POLITEKNIK LP3I
}

\author{
Lulu Ulfa Sholihannisa, Poniah Juliawati ${ }^{1}$ \\ Politeknik LP3I \\ e-mail: 1uluulfasholihannisa@plb.ac.id, poniahjuliawati@plb.ac.id
}

\begin{abstract}
Abstrak : Penelitian ini bertujuan untuk mengetahui manajemen pembelajaran pada pendidikan tinggi vokasi dengan menggunakan model pembelajaran block system learning. Penelitian ini dilakukan di Politeknik LP3I dengan menggunakan metode penelitian deskriptif kualitatif dan objek penelitian Dosen Polireknik LP3I Bandung. Pengambilan data dilakukan dengan cara melakukan observasi, wawancara, dokumentasi, dan angket. Hasil penelitian diketahui bahwa: 1) pada perencanaan model pembelajaran block system learning, dosen terlibat dalam perancangan kurikulum PT, termasuk silabus dan RPS mata kuliah memperoleh rerata yang paling tinggi sebesar 4,03\%; 2) pelaksanaan model pembelajaran block system learning, dosen melaksanakan pembelajaran sesuai dengan tuntutan kurikulum dan kebutuhan kompetensi mahasiswa memperoleh rerata sebesar $3.85 \%$; 3) penilaian dan evaluasi dilakukan dengan cara menentukan prosedur penilaian yang memperoleh rerata sebesar 3,74\%, serta Melakukan peniliaian dengan menggunakan tes dalam bentuk teori dan praktikum memperoleh rerata sebesar 4,10\%; 4) sebagai faktor pendukung, Institusi memberikan kebebasan dalam pengembangan kurikulum pembelajaran sesuai dengan KKNI dan SKKNI mendapat rerata sebesar 3,65\%. Adapun yang menjadi faktor penghambat dalam pembelajaran dengan model block system learning, dosen Mengalami gangguan pada fasilitas yang bersifat software maupun hadware terhadap perencanaan, pelaksanaan, dan evaluasi pembelajaran dengan rerata sebesar 4,00\%; 5) Dampak capaian kompetensi mahasiswa sesuai dengan kurikulum PT yang berjalan memperoleh rerata sebesar 3.83\%.
\end{abstract}

Kata Kunci : Model, Block System, learning

\section{Pendahuluan}

Berbicara mengenai pendidikan, seolah-olah tidakakan pernah habis untuk menjadi topic pembahasan yang tidak hanya dibahas oleh kalangan pendidikan saja, akan tetapi masalah pendidikan ini selalu menjadi primadona yang menjadi perhatian diberbagai kalangan. Tuntutan pendidikan demi kemajuan bangsa menjadi faktor utama tercapainya pendidikan yang sempurna dan menyeluruh. Peran orang tua, lingkungan, guru atau dosen juga menjadi faktor yang berpengaruh terhadap tercapainya tujuan pendidikan tersebut. Dalam menjalankan pendidikan yang utuh dan menyeluruh harus ditunjang oleh SDM yang kompeten, karena dengan SDM yang kompeten dalam menjalan roda pendidikan tentu ketercapaian pendidikan pun akan memperoleh SDM yang kompeten pula, yang siap kerja sesuai dengan DUDI. Untuk meningkatkan kualitas pendidikan yaitu dengan melakukan manajemen atau mengelola pembelajaran pendidikan.

Sebagai contoh pada penelitian yang dilakukan oleh Asnah Said dkk. (Said, 2014:52) dengan tema "PKP Supervision Model Development Using The Block System Tutorial To Enhance The Tearcher Professional Competence" menjelaskan sebagai identifikasi awal 
bahwa tutorial tatap muka dengan block system telah diimplementasikan hanya pada mahasiswa di kepulauan Nias Barat semester 1 tahun 2005, dan demikian pula dengan supervisi pengajaran kepada mahasiswa dengan bentuk Pemantapan KemampuanProfesional (PKP) yang dilakukan pada semester 1 tahun 2007.

Adapun bentuk manajemen pembelajaran yang akan diteliti pada penelitian ini adalah bentuk manajemen pembelajaran model block system learning atau yang sering dikenal dengan istilah pembelajaran sistem blok. Pada beberapa jenjang pendidikan vokasi, model block system sudah banyak diterapkan. Dalam kurikulum pendidikan vokasi, model blok merupkan struktur kurikulum pararel yang tidak termasuk atau tidak berdasarkan pada kurikulum pembelajaran semester, karena model ini lebih menuntut keteracapaian kompetensi mata kuliah tertentu, seperti dibuat dalam bentuk modular karena terdiri dari dari beberapa bentuk modul/blok. Namun, tidak seluruh komponen kurikulum pembelajaran dapat dibuat dalam bentuk modular/blok, ada juga yang bentuk model block system berupa semesteran seperti yang berjalan pada umumnya, akan tetapi dibuat model block system dengan mengelompokan beberapa mata kuliah berdasarkan kompetensi yang sama atau sejenis. Sehingga pada capaian semester akan mengacu pada capaian kompetensi yang sama atau serupa dan haru tuntas pada semester terebut tanpa harus menjadi prasyarat untuk mengikuti atau mengontrak mata kuliah selanjutnya.

Politeknik LP3I merupakan pendidikan tinggi yang menganut kurikulum link and match yaitu penyesuaian pembelajaran pada jenjangan pendidikan vokasi yang menyesuaikan dengan tuntutan dunia usaha dan dunia industri (DUDI). Dengan program unggulan D3, Politeknik LP3I harus mempersiapkan mahasiswa untuk siap bekerja dan bersaing di dunia kerja. Sesuai dengan capaian pembelajaran dalam KKNI melalui PERPRES 08/2012 dan PERMENRISTEKDIKTI 44/2015 yang dikembangkan oleh Tim Pengembangan Kurikulum Pendidikan Tinggi Direktorat Pembelajaran Ditjen Belmawa Kemenristekdikti tahun 2017 untuk program D3 menduduki level 5 yaitu menguasai konsep teoritis bidang pengetahuan tertentu secara umum, serta mampu memformulasikan permasalahan prosedural. Hal ini dapat dilihat dari gambar berikut ini:

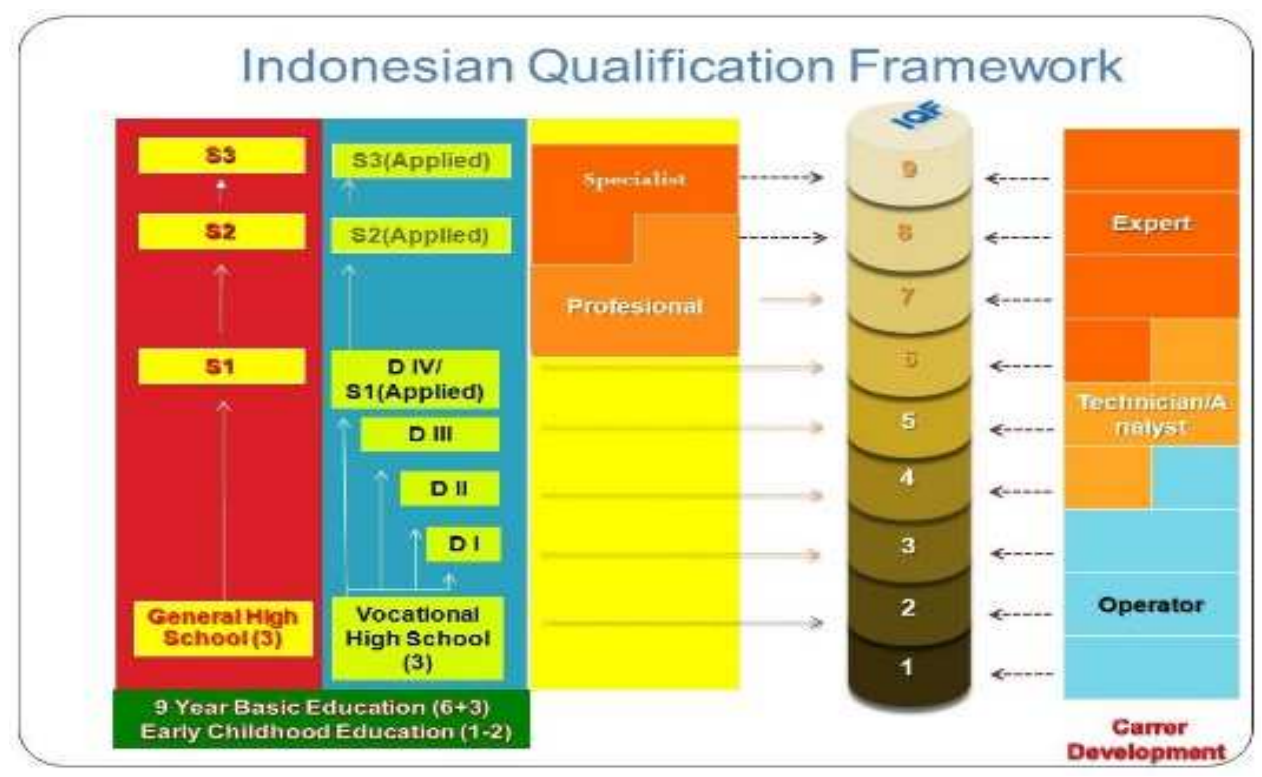

Gambar 1. Kerangka Kualifikasi Nasional Indonesia (sumber: Panduan KKNI dan SN-DIKTI, 2017:4) 
Untuk memperoleh hasil capaian model pembelajaran model block system learning di Politeknik LP3I, maka peneliti merasa perlu untuk melakukan penelitian dalam bentuk manajemen pembelajaran yaitu mulai dari bentuk perencanaan, pelaksanaan, penilaian dan evaluasi, serta menemukan faktor pendukung dan penghambat pembelajaran dengan model block system learning. Hal-hal tersebut merupakan bentuk batasan masalah sekaligus menjadi tujuan penelitian yang akan diteliti.

\section{Konsep Model Block System}

Model pembelajaran dalam proses pembelajaran merupakan sutu rangkaian penyampaian materi pembelajaran yang dilakukan oleh pendidik selama proses pembelajaran tersebut berlangsung. Efektivitas suatu pembelajaran dapat memberikan fasilitas untuk mencapai pengetahuan, keterampilan, dan kompetensi secara maksimal.

Pembelajaran yang dilaksanakan di Politeknik LP3I lebih banyak menggunakan pembelajaran praktikum. Dengan demikian penyesuaian model block system learning yang dipadukan dengan pembelajaran praktikum sangat cocok dan lebih efektif. Karena selain menuntut dan mengembangkan kemampuan kognitif mahasiswa, kemampuan motorik mahasiswa pun terus dilatih dan dikembangkan secara terus menerus dengan waktu yang telah ditetapkan.

Sesuai dengan kurikulum pendidikan tinggi pada Buku Panduan Penyusunan Kurikulum Pendidikan Tinggi RISTEKDIKTI 2016 (2016: 4) mata kuliah atau modul dibentuk berdasarkan pertimbangan kemandirian materi cabang / ranting /bahan kajian bidang keilmuan tertentu atau unit keahlian tertentu (parsial) atau pertimbangan pembelajaran terintegrasi dari sekelompok bahan kajian atau sejumlah keahlian (sistem blok) dalam rangka pemenuhan capaian pembelajaran lulusan yang dirumuskan dalam kurikulum.

Pada penelitian model block scheduling yang dilakukan oleh Schot (2008) yang dikutip oleh Majid, dkk. (2011: 37) menjelaskan bahwa terdapat dampak penggunaan pembelajaran dengan model tersebut, yaitu: (1) Pendidik dapat menggunakan strategi pembelajaran yang bervariatif dan metode yang inovatif karena waktu tatap muka yang lebih lama; (2) Waktu untuk sebuah pembelajaran yang efektif dapat lebih lama hal ini dikarenakan terbuangnya waktu untuk pembukaan kelas, penjelasan tujuan atau aturanaturan lain dalam pembelajaran serta rutinitas lain seperti absensi dan lain sebagainyadapat dikurangi karena jumlah tatap muka menjadi lebih sedikit; (3) Tatap muka antara peserta didik dan pendidik akan berlangsung lebih lama sehingga akan menjadikan pengembangna materi yang lebih dalam dan pengembangan yang lebih kritis. Serta memungkian pendidik untuk berinteraksi dengan seluruh peserta didik di dalam kelas; (4) Adanya pertemuan ynag berlangsung sehari atau 8 jam pelajaran, maka peserta didik akan terdorong untuk selalu menghadiri pembelajaran (tatap muka), dengan demikian kehadiran peserta didik akan lebih meningkat; (5) Peserta didik tidak dibebani dengan mata pelajaran (dalam hal ini perkuliahan mahasiswa) yang banyak sehingga dapat mengurangi tekanan akibat beban belajar yang ditimbulkan oleh mata pelajaran yang bervariasi.

Namun selain dari dampak positif dari model block system learning, tidak selamanya model-model pembelajaran dapat diterapkan dalam seluruh mata pelajaran atau mata kuliah. Pada pembelajaran mata kuliah bidang humaniora seperti bahasa inggris, Bahasa 
Indonesia, sejarah dan beberapa mata kuliah lainnya, justru hasil capaian pembelajaran yang diperoleh akan menurun. Hal tersebut dinyatakan oleh Schott (2008) yang dikutip oleh Majid, dkk. (2011: 37) yaitu kekurangan model block system antara lain: (1) Beberapa jenis mata pelajaran seperti matematika dan membaca tidak ditemukannya perbedaan yang signifikan atas hasil yang diperoleh jika dibandingkan dengan pembelajaran yang menggunakan model penjadwalan tradisional; (2) Beberapa mata pelajaran tertentu model penjadwalan ini akan berakibat menurunkan hasil pembelajaran seperti pada penelitian Lawrence Mc Pherson (2000) yaitu pada mata pelajaran Biologi, Bahasa Inggris, dan Sejarah; (3) Permsalahan pada ingatan peserta didik dimana peserta akan menirama sebuah mata pelajaran hanya dalam beberapa waktu saja misalkan hanya dalam satu minggu dan tidak akan berulang pada waktu selanjutnya, hal ini lah yang dianggap tidak akan mampu menyebabkan ingatan pada mata pelajaran tersebut menjadi tidak permanen ada pada peserta didik; (4) Akan sulit bagi peserta didik jika tidak dapat mengikuti pembelajaran walaupun hanya sekali saja, hal ini dikarenakan dalam sekali tatap muka akan berlangsung lebih lama dari pada model penjadwalan tradisional.

Selain itu pada penelitian yang dilakukan oleh Johandi, dkk (2016: 9) mengenai pengaruh pembelajaran block system terhadap prestasi belajar proses industri kimia siswa kelas XI SMTI Pontianak, dijelaskan bahwa terdapat perbedaan prestasi belajar mata pelajaran PIK antara siswa yang diberi pembelajaran block system dengan siswa yang hanya diberi pembelajaran harian, dan besar pengaruh penerapan pembelajaran block system terhadap peningkatan prestasi belajar sebesar 28,23\%.

\section{Metode Penelitian}

Penelitian ini menggunakan metode deskriptif kualitatif. Fokus penelitian ini adalah manajemen pembelajaran pada pendidikan vokasi di Politeknik LP3I sekaligus menjadi tempat penelitian. Penelitian ini dilaksanakan mulai bulan Maret sampai bulan Juni 2019. Subjek penelitian ini adalah seluruh pihak yang terlibat dalam kegiatan pembelajaran yaitu dosen, mahasiswa, bagian akademik, dan ketua/sekretaris (manajemen) prodi. Sedangkan yang menjadi objek penelitian ini adalah manajemen pembelajaran model block system learning yang meliputi perencanaan, pelaksanaan, penilaian dan evaluasi, serta faktor pendukung dan penghambat model pembelajaran, serta dampat dari block system learning pada pendidikan vokasi.

Teknik Pengumpulan data pada penelitian ini adalah dengan menggunakan observasi dan wawancara. Instrumen pengumpulan data adalah peneliti sendiri yang bersifat naturalistik dan tidak ada pilihan lain selain menjadikan manusia sebagai instrumen penelitian utama. Hal ini sesuai dengan paparan Jabar bahwa kategori Instrumen yang baik dalam penelitian kualitatif adalah instrument yang memiliki pemahaman yang baik akan metodologi penelitian, penguasaan wawasan terhadap bidang yang diteliti, kesiapan untuk memasuki objek penelitian, baik secara akademik maupun logistik. Hal ini juga sejalan dengan ungkapan Sugiono (2006: 251) peran peneliti sebagai key instrument. Dengan demikian, pada penelitian ini juga peneliti sebagai pewawancara yang bertugas untuk mengumpulkan data dengan cara bertanya, meminta, mendengar jawaban langusng dari sumber secara langsung.

Observasi atau pengamatan yang dilakukan dalam penelitian ini yaitu dengan melakukan pencatatan objek penelitian mulai dari suasana kegiatan pemelajaran di dalam kelas, 
gedung dan sarana prasarana di lingkungan kampus Politeknik LP3I, serta karyawan bagian akademik dan prodi.

Dokumentasi yang dilaksanakan adalah dengan mengumpulkan dokumen-dokumen yang berkaitan dengan penelitian, antara lain daftar dosen dan manajemen (karyawan) bidang akademik dan prodi, dokumen keorganisasian Politeknik LP3I, foto-foto kegiatan, administrasi pembelajaran akademik seperti kalender akademik, silabus, RPS, modul dan bahan ajar.

Wawancara dilakukan kepada Wakil Direktur I Bidang Akademik, Kabag. Akademik, Ketua Prodi, Koordinator Mata Kuliah, dan Dosen. Hal ini dimaksudkan untuk memperoleh informasi yang berhubungan dengan manajemen pembelajaran model block system learning sesuai dengan batasan masalah dan tujuan penelitian yang meliputi perencanaan, pelaksanaan, penilaian dan evaluasi, serta menemukan faktor pendukung dan penghambat, dan dampak dar pembelajaran dengan model block system learning pada pendidikan.

Untuk menguji keabasahan data pada penelitian ini, dilakukan melalui kredibilitas data atau derajat kepercayaan data, untuk menguji kepercayaan atau kredibilitas data dilakukan dengan cara teknik triangulasi baik triangulasi sumber ataupun triangualasi metode yaitu dengan melakukan perbandingan data informasi yang diperoleh antara Wakil Direktur 1 dan Kabag. Akademik. Adapun triangulasi metode yaitu dengan membandingkan data hasil wawancara dengan catatan lapangan antara Kaprodi/Sekprodi dan dosen. Selain hal tersebut, dilakukan uji keabsahan data wawancara dengan melakukan konfirmasi antara hasil wawancara dengan informan.

Penggunaan metode triangulasi ini dilakukan untuk mendapatkan jawaban yang jelas, seperti terlihat pada hasil wawancara berikut ini:

Tabel. Bentuk Triangulasi Metode

\begin{tabular}{|c|c|c|}
\hline $\begin{array}{l}\text { il Direktur } 1 \\
\text { g Akademik }\end{array}$ & DI & Dosen \\
\hline $\begin{array}{l}\text { PT mempunyai } \\
\text { kurikulum yang sudah } \\
\text { terstruktur yang } \\
\text { disesuaikan dengan } \\
\text { kebutuhan dunia kerja. } \\
\text { Oleh sebab itu, untuk } \\
\text { menunjang hal tersebut, } \\
\text { model pembelajaran } \\
\text { harus menjadi perhatian } \\
\text { bagi seluruh stake holder } \\
\text { kampus khususnya prodi } \\
\text { dan dosen. Sebagai jantuk } \\
\text { institusi, bidang } \\
\text { akademik kampus yang } \\
\text { dibantu oleh prodi } \\
\text { membuat tim coordinator }\end{array}$ & $\begin{array}{l}\text { Salah satu tugas prodi } \\
\text { adalah melakukan } \\
\text { perencanaan dan evaluasi } \\
\text { terhadap mata kuliah } \\
\text { yang pelaksanaannya } \\
\text { dilakukan oleh dosen di } \\
\text { dalam kelas. } \\
\text { Oleh sebab itu, prodi } \\
\text { membuat tim coordinator } \\
\text { mata kuliah yang } \\
\text { bertujuan memberikan } \\
\text { kemudahan kepada dosen } \\
\text { dalam persiapan } \\
\text { pelaksanaan } \\
\text { pembelajaran, sehingga } \\
\text { tidak ada lagi dosen yang }\end{array}$ & $\begin{array}{lr}\text { Sebagai pelakasana } \\
\text { dilapangan (di kelas) } \\
\text { dosen } \\
\text { mempunyai } \begin{array}{r}\text { memang } \\
\text { yang sangat besar. }\end{array} \\
\text { Apalagi bagi dosen yang } \\
\text { mengampu pada mata } \\
\text { kuliah-mata kuliah } \\
\text { tertentu yang menuntut } \\
\text { seluruh mahasiswa } \\
\text { kompeten dengan waktu } \\
\text { yang telah ditentukan } \\
\text { namun tidak menjadi } \\
\text { syarat untuk mengambil } \\
\text { atau mengontrak } \\
\text { matakuliah diatasnya. }\end{array}$ \\
\hline
\end{tabular}




\begin{tabular}{|l|l|l|}
\hline $\begin{array}{l}\text { pada masing-masing } \\
\text { mata kuliah. }\end{array}$ & $\begin{array}{l}\text { tidak siap untuk } \\
\text { melakukan pengajaran. }\end{array}$ & \\
\hline
\end{tabular}

Berikutnya adalah contoh triangulasi teknik, yang digunakan peneliti untuk melakukan pengecekan informasi antara hasil wawanca dengan dokumen.

Tabel 2. Bentuk Triangulasi Teknik

\begin{tabular}{|c|c|c|}
\hline \multicolumn{2}{|r|}{ Wawancara } & Dokumen \\
\hline Penanya & $\begin{array}{l}\text { Pak/Bu apakah seluruh dosen wajib membuat } \\
\text { perencanaan pembelajaran? Bentuknya seperti } \\
\text { apa? }\end{array}$ & $\begin{array}{l}\text { Silabus \& } \\
\text { RPS }\end{array}$ \\
\hline $\begin{array}{l}\text { Jawab } \\
\text { Prodi (Man. } \\
\text { Informatika) }\end{array}$ & $\begin{array}{l}\text { Ya, dosen wajib mempersiapkan perencaan } \\
\text { pembelajaran, namun tidak diwajibkan untuk } \\
\text { membuat Silabus dan RPS, karena sudah } \\
\text { dipersiapkan oleh tim atau koordinator mata } \\
\text { kuliah, sehingga dosen pengampu mata kuliah } \\
\text { hanya dituntut untuk melakukan pengembangan } \\
\text { saja dari silabus dan RPS tersebut berupa bahan } \\
\text { ajar yang akan diberikan kepada mahasiswa }\end{array}$ & \\
\hline
\end{tabular}

Tahapan akhir dari penelitian ini adalah dengan melakukan analisis data. Analisis data yang peneliti lakukan dalam penelitian ini adalah dengan cara mereduksi data, menyajikan data, dan menarik kesimpulan terhadap peristiwa-peristiwa yang dilakukan dan dikumpulkan dari hasil observasi, dokumentasi, dan wawancara. Selain itu, untuk menganalisis data hasil observasi dan dokumentasi, peneliti juga mengatur dan mengelompokan sesuai data dan aspek yang diamati. Menentukan tingkat skor masingmasing aspek, menghitung frekuensi untuk tiap-tiap aspek yang diamati. 
Adapun tahapan penelitian ini dapat dilihat dari alur gambar dibawah ini:

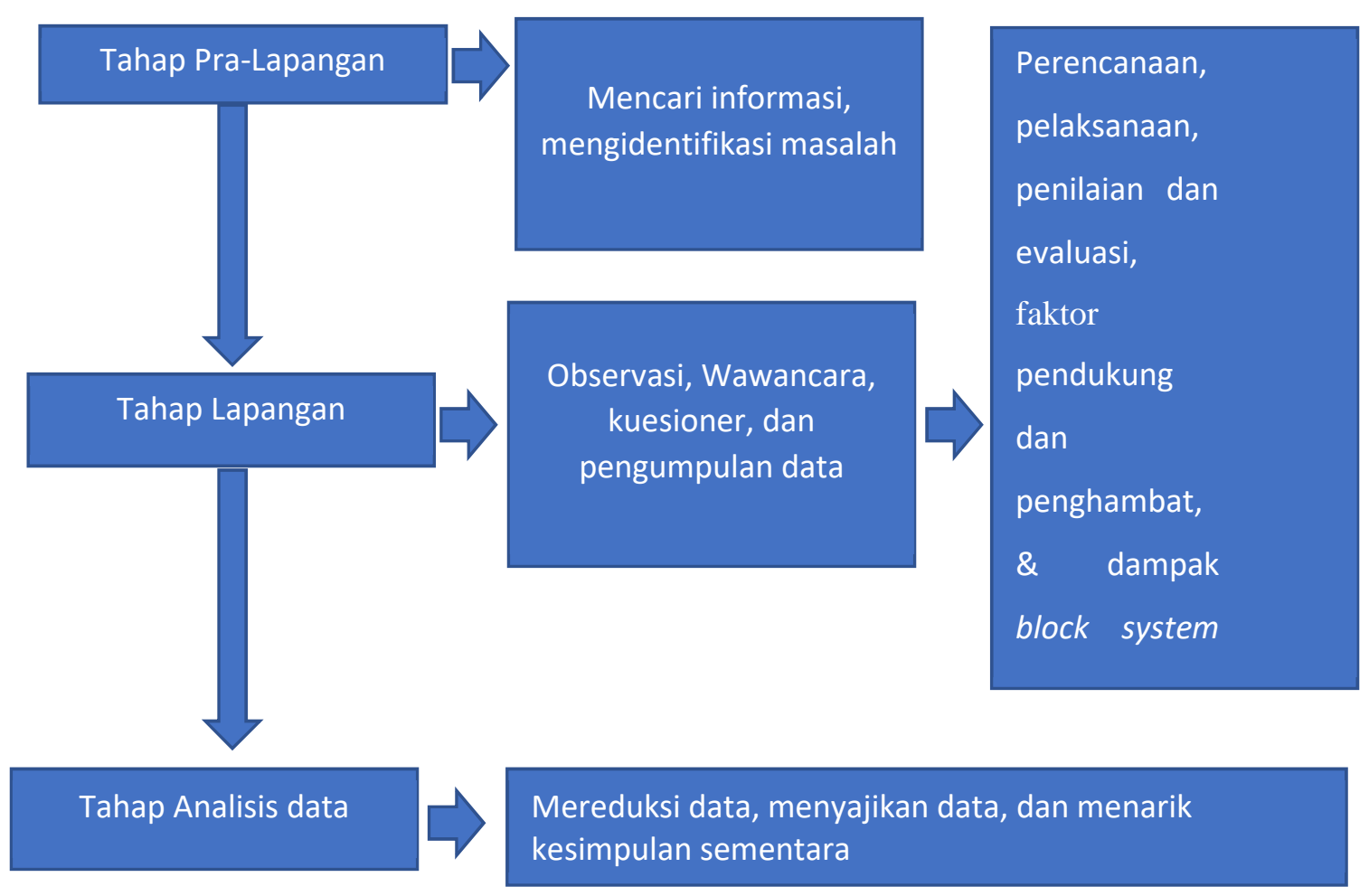

Gambar 2. Alur Tahapan Penelitian

\section{Hasil dan Pembahasan}

Proses pendidikan tidak akan pernah lepas dari kurikulum dan proses pembelajaran. Pada pendidikan tinggi, tercapainya tujuan pendidikan yang paripurna adalah peserta didik yang disiapkan untuk menjadi anggota masyarakat sesuai dengan kompetensi yang dimiliki yang diterap dan dikembangkan sebagai seorang anggota masyarakat yang profesinal. Hal ini dinyatakan dalam PERMEN RI No 60 Tahun 1999 tentang Pendidikan Tinggi menjelaskan bahwa Tujuan Pendidikan Tinggi yang tercantum dalam Bab II Pasal 2 yaitu a) menyiapkan peserta didik menjadi anggota masyarakat yang memiliki kemampuan akademik dan/atau professional yang dapat menerapkan, mengembangkan, dan/atau memperkaya khasanah ilmu pengetahuan, teknologi dan/atau kesenian; b) mengembangkan dan menyebarluaskan ilmu pengetahuan, teknologi dan/atau kesenian serta mengupayakan penggunaannya untuk meningkatkan taraf hidup masyarakat dan memperkaya kebudayaan nasional. Sejatinya proses pembelajaran harus bersifat efektif, interaktif, holisti, saintifik, kolaboratif, dan yang paling utama adalah berpusat pada peserta didik.

Pembelajaran akan efektif apabila selama proses pembelajaran dibantu dengan menggunakan model, pendekatan, strategi, metode, teknik, dan media yang tepat dan sesuai dengan tipe atau karakter mata kuliah tersebut yang diperuntukan untuk memperoleh capaian pembelajaran yang sudah ditetapkan. Menurut Daulae (2014: 134) pembelajaran yang efektif adalah yang menghasilkan belajar yang bermanfaat dan bertujuan kepada para mahasiswa melalui pemakaian prosedur yang tepat. 
Definisi ini mengandung 2 indikator yang penting, yaitu terjadinya belajar pada mahasiswa dan apa yang dilakukan oleh dosen. Proses pembelajaran dalam Pendidikan Tinggi harus mempunyai standar. Proses pembelajaran seperti karakteristik pembelajaran, perencanaan proses pembelajaran, pelaksanaan proses pembelajaran, dan beban belajar mahasiswa. hal tersebut tercantum dalam PERMENRISTEKDIKTI No 44 Tahun 2015 tentang SNPT bab II bagian ke-4 pasal 10 ayat $1 \& 2$. Dengan demikian, agar komponen tersebut terpenuhi, pada penelitian ini sesuai dengan batasan masalah dan tujuan penelitian mengenai manajemen pembelajaran model block system learnig, maka ditemukan hasil penelitian sebagai berikut:

\section{a. Perencanaan Pembelajaran Model Block System Learning}

Pada tahap ini diawali dengan melakukan FGD beberapa tim kegiatan akademik, yang terdiri dari penyusun perancangan perencanaan pembelajaran kurikulum dengan model block system learning pada pendidikan vokasi. Tim penyusun perancangan perencanaan pembelajaran tersebut terdiri dari Wakil Direktur 1 bidang akademik, Kabag Akademik, dan Ketua/Sekprodi sebagai Tim pertama. Tim koordinator mata kuliah adalah Ketua/Sekprodi dan ketua koordinator mata kuliah beserta dosen pengampu mata kuliah bertindak sebagai Tim kedua.

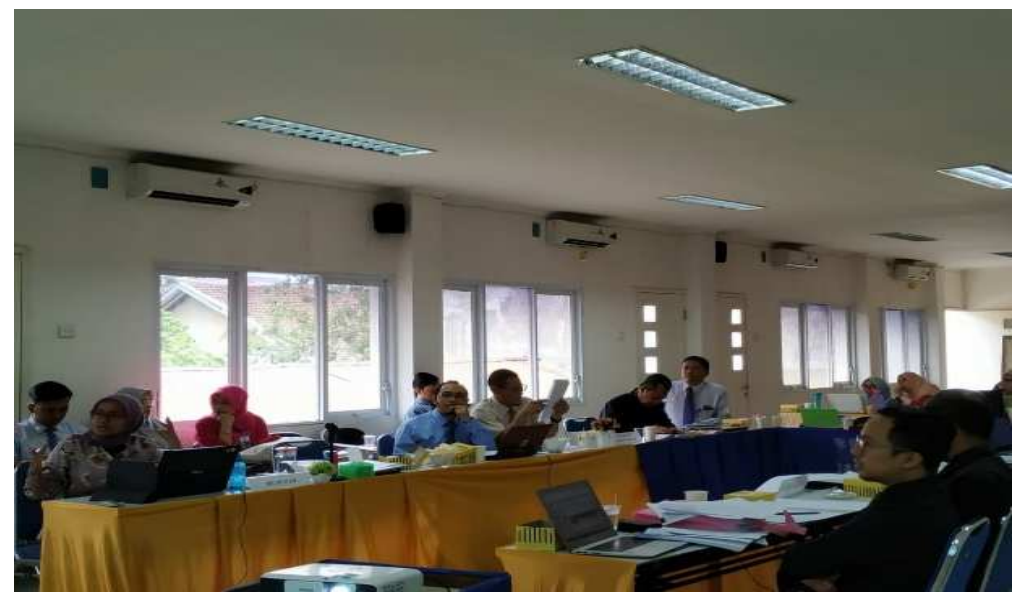

Gambar 3. FGD Model pembelajaran

Tim pertama mempunyai tugas untuk menentukan dan mengelompokan mata kuliah yang bersifat atau berstruktur yang mempunyai kompetensi yang sama pada semester yang telah ditentukan tanpa harus menjadi syarat bagi mata kuliah yang selanjutnya atau bersifat modular. Hal ini juga berhubungan dengan bentuk kurikulum pendidikan vokasi sebagai program untuk mencapai kompetensi lulusan atau output yang harus dilaksanakan. Merujuk pada PERMENRISTEKDIKTI No. 44 Tahun 2015 tentang SNPT, tugas yang dilakukan oleh tim kedua sebagai bentuk perencanaan model pembelajaran block system learning adalah menyusun silabus dan RPS yang dikembangkan oleh dosen coordinator mata kuliah sesuai dengan pengelompokan mata kuliah pada Prodi masing-masing dengan menyesuaikan pada kalender akademik serta membuat modul bahan ajar perkuliahan. 
Salah satu kegiatan penelitian yang dilakukan adalah melakukan wawancara pada prodi Manajemen Informatika yang diwakili oleh Sekretaris Prodi Manajemen Informatika.

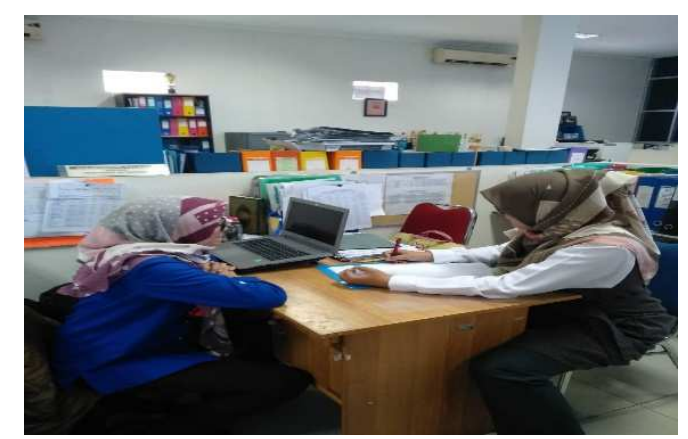

Gambar 4. Wawancara dengan Sekprodi Manajemen Informatika

Pada semester pertama mahasiswa diberikan sistem paket, jadi dalam satu kelas terdiri dari seluruh program study mahasiswa. Sedangkan pada semester berikutnya, mahasiswa sudah terklasikal yang terdiri dari 25 mahasiswa dengan prodi yang sama. Sebagai contoh pada mata kuliah Computer for Data Base. Pada mata kuliah ini, mahasiswa memperoleh kompetensi mengenal apa itu database, mengetahui sistem manajemen basis data (DBMS), memenej interaksi antara user, end user, dan database, mengetahui lingkup sistem basis data, jaringan database, relasi antar data, dan software database. Untuk penilaian dan evaluasi akhir yaitu mahasiswa harus membuat satu database dengan software database dalam bentuk praktek. Berikut model block system yang terdapat di prodi Manajemen Informatika: 


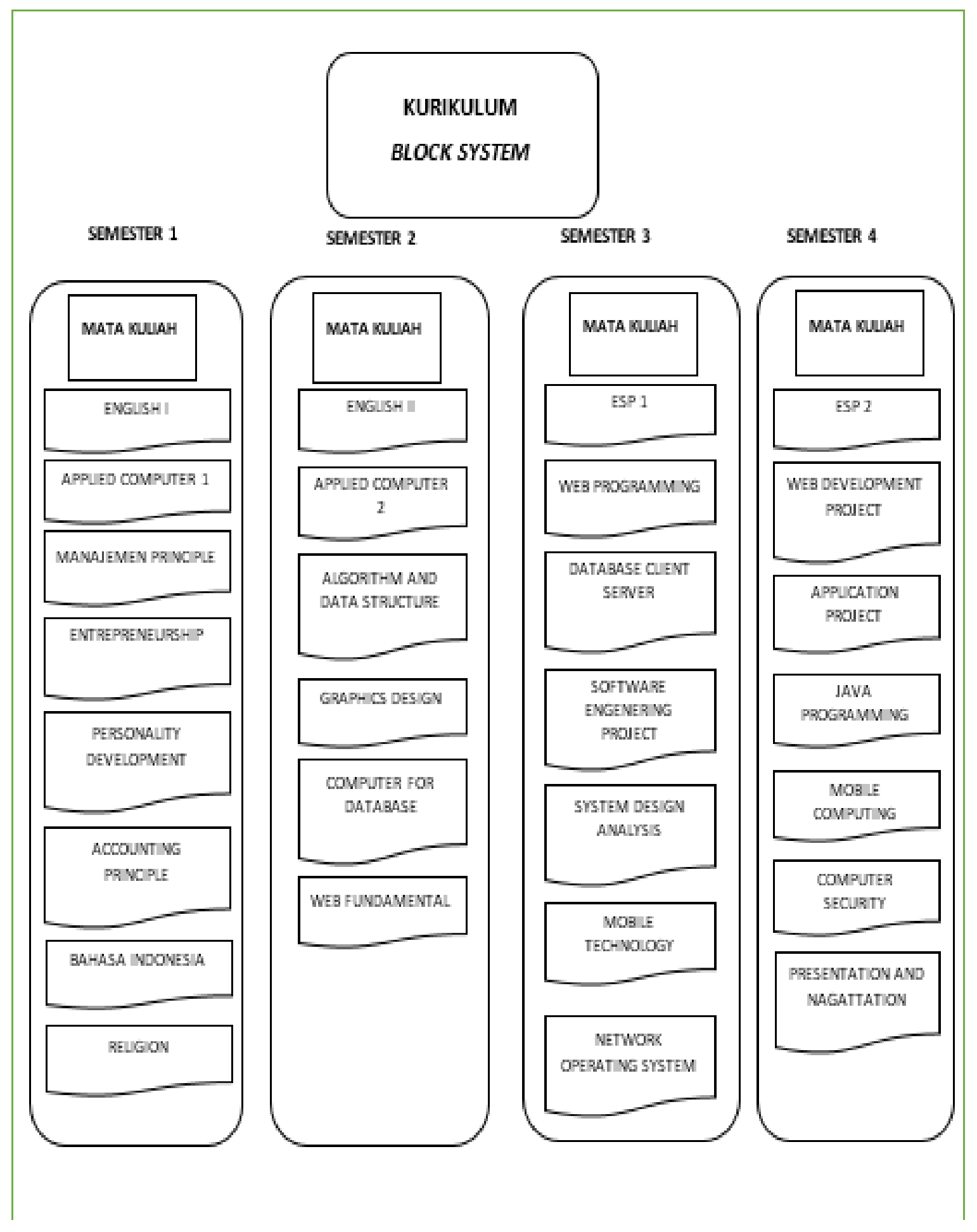

Gambar 5. Blok Kurikulum Mananjemen Informatika Konsentrasi Informatika Manajemen

Hasil yang diperoleh dilapangan melalui kuesioner pada tahap perencanaan pembelajaran model block system learning dapat dlihat pada tabel berikut ini: 
Tabel 3. Hasil persentase angket kuesioner perencanaan pembelajaran

\begin{tabular}{|c|c|c|c|}
\hline \multirow{2}{*}{ No. } & Aspek-aspek & $\begin{array}{c}\text { Rerata } \\
\%\end{array}$ & \multirow{2}{*}{$\begin{array}{c}\begin{array}{c}\text { Persentase } \\
\text { aspek }\end{array} \\
22.82 \%\end{array}$} \\
\hline & \multicolumn{2}{|l|}{ Perencanaan } & \\
\hline 1. & $\begin{array}{l}\text { Saya mengetahui tentang Kurikulum PT yang berjalan } \\
\text { ditempat saya mengajar }\end{array}$ & 3.70 & \\
\hline 2. & $\begin{array}{l}\text { Saya terlibat dengan perancangan kurikulum PT, termasuk } \\
\text { silabus dan RPS mata kuliah yang saya ampu }\end{array}$ & 4.03 & \\
\hline 3. & $\begin{array}{l}\text { Kurikulum PT yang berjalan sesuai dengan SNDIKTI, } \\
\text { KKNI dan SKKNI }\end{array}$ & 3.83 & \\
\hline 4. & $\begin{array}{l}\text { Perencanaan pembelajaran yang saya buat sesuai dengan } \\
\text { panduan perancangan kurikulum PT }\end{array}$ & 3.76 & \\
\hline 5. & $\begin{array}{l}\text { Memahami komponen perencanaan pembelajaran } \\
\text { khususnya RPS sesuai dengan silabus kurikulum PT }\end{array}$ & 3.63 & \\
\hline 6. & $\begin{array}{l}\text { Perancangan pengembangkan tujuan pembelajaran } \\
\text { berdasarkan SKKNI }\end{array}$ & 3.87 & \\
\hline
\end{tabular}

Dari hasil tabel diatas dapat diketahui bahwa perancangan kurikulum PT termasuk silabus dan RPS mata kuliah yang terdapat pada point nomor 2 dengan rerata 4.03\% menunjukan bahwa tingkat keterlibatan dosen sangat tinggi, sedangkan point nomor 6 yaitu perancangan pengembangkan tujuan pembelajaran berdasarkan SKKNI memperoleh rerata sebesar 3.87 sebagai bentuk perencanaan rerata tertinggi kedua. Adapun persentase aspek perencanaan memperoleh jumlah rerata presentase $22.82 \%$.

\section{b. Pelaksanaan Pembelajaran Model block system learning}

Rettig (2018, 8) menjelaskan bahwa dalam pelaksanaan model block system learning terdapat kriteria perbandingan penjadwalan, antara lain: 1) waktu per mata pelajaran; 2) pilihan yang tersedia; 3) biaya; 4) beban atau muatan mahasiswa; 5) beban atau muatan guru; 6) persentase inti (diasumsikan 1 kelas persemester/periode atau dalam bentuk blok); 7) dalam format kumpulan kelompok.

Hasil yang diperoleh dilapangan melalui kuesioner pada tahap pelaksanaan pembelajaran model block system learningdapat dlihat pada tabel berikut ini: 
Tabel 4: Hasil persentase angket kuesioner pelaksanaan pembelajaran

\begin{tabular}{|c|c|c|c|}
\hline \multirow{2}{*}{ No. } & Aspek-aspek & $\begin{array}{l}\text { Rerata } \\
\%\end{array}$ & $\begin{array}{l}\text { Persentase } \\
\text { Aspek }\end{array}$ \\
\hline & \multicolumn{2}{|l|}{ Pelaksanaan } & $22.93 \%$ \\
\hline 1. & $\begin{array}{l}\text { Melakukan kegiatan pembelajaran sesuai dengan } \\
\text { perencanaan yang telah ditetapkan (RPS) }\end{array}$ & 3.78 & \\
\hline 2. & $\begin{array}{l}\text { Melaksanakan pembelajaran sesuai dengan tuntutan } \\
\text { kurikulum dan kebutuhan kompetensi mahasiswa }\end{array}$ & 3.85 & \\
\hline 3. & $\begin{array}{l}\text { Memberikan berbagai contoh studi kasus pada setiap } \\
\text { pembelajaran }\end{array}$ & 3.87 & \\
\hline 4. & Iklim Pembelajaran berjalan hanya satu arah & 4.10 & \\
\hline 5. & $\begin{array}{l}\text { Mengembangkan materi pembelajaran untuk dipraktikan } \\
\text { mahasiswa }\end{array}$ & 3.61 & \\
\hline 6. & $\begin{array}{l}\text { Mahasiswa diberikan kebebasan untuk berargumentasi } \\
\text { dalam menyampaikan pendapat dalam pembelajaran }\end{array}$ & 3.72 & \\
\hline
\end{tabular}

Dari aspek pelaksanaan pembelajaran model block system learning, memperoleh persentase sebanyak $22.93 \%$. Iklim pembelajaran pada umumnya harus dilakukan dalam multi arah, sedangkan pada pembelajaran dengan model block system learning memang harus diutamakan dengan satu arah, karena yang menjadi tujuan capaian pembelajara adalah keberhasilan kompetensi mahasiswa. Dengan kata lain mahasiswa harus lebih aktif, kreatif, dan inovatif dalam kegiatan pembelajaran.

Hal tersebut dapat dilihat dari point nomor 5 dan 6 dengan rerata $3.61 \%$ dan $3.72 \%$, hal ini berarti dosen selalu mengembangkan dan memberikan kebebasan berargumentasi serta menyatakan pendapat dalam materi pembelajaran untuk dipraktikan agar mahasiswa dapat mengembangkan kompetensi mereka. Sebagai contoh apabila mahasiswa diberikan satu study kasus, mahasiswa tersebut harus mampu untuk menemukan cara atau langkah dalam menangani kasus yang ia hadapi salah satunya mahasiswa harus mempunyai problem solving. Contoh tahap pelaksanaan dalam proses pembelajaran dapat dilihat juga pada gambar di bawah ini:

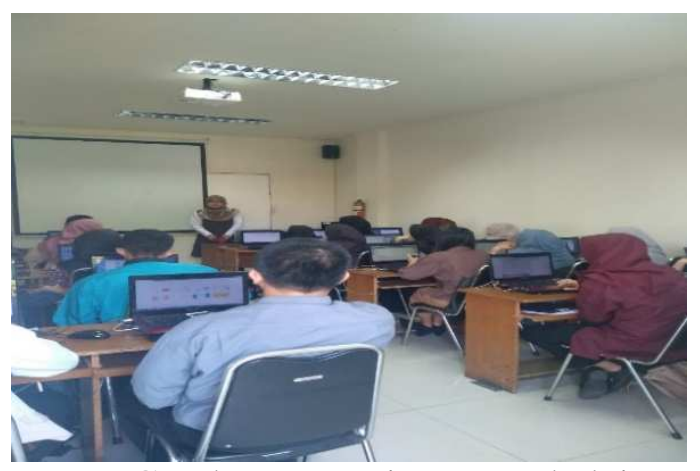

Gambar 6. Kegiatan pembelajaran 


\section{c. Penilaian dan evaluasi pembelajaran model block system learning}

Dalam pembelajaran dan kurikulum, penilaian serta evaluasi merupakan syarat untuk mengetahui ketercapaian tujuan dari kurikulum dan pembelajaran yang telah ditentukan. Menurut Ibrahim dan Masitoh (2011: 6) dalam materi perkuliahan Evaluasi Kurikulum Fakultas Ilmu Pendidikan UPI menjelaskan bahwa "model evaluasi yang telah dikembang dapat digolongkan menjadi empat rumpun model penilaian dan evaluasi antara lain: 1) measurement. Yaitu pengukuran perilaku siswa untuk mengungkapkan perbedaan individual maupun kelompok; 2) congruence. Yaitu kesesuaian antara tujuan dan hasil belajar yang dicapai, untuk melihat sejauh mana perubahan hasil pendidikan telah terjadi; 3) illumination. Model ini lebih didasarkan pada judgement (pertimbangan) yang hasilnya diperlukan untuk penyempurnaan program yang mencakup objek evaluasi seperti latar belakang dan perkembangan program, proses pelaksanaan, hasil belajar dan kesulitan- kesulitan yang dialami; 4) educational system evaluation. Pada dasarnya model ini melakukan perbandingan dan performance setiap dimensi program dan kriteria yang akan berakhir dengan suatu deskripsi dan judgement.

Dengan demikian, pada tahap penilaian dan evaluasi pembelajaran model block system learning diperoleh hasil sebagai berikut:

Tabel 5. Hasil persentase angket kuesioner penilaian dan evaluasi pembelajaran

\begin{tabular}{|c|c|c|c|}
\hline \multirow{2}{*}{ No. } & Aspek-aspek & $\underset{\%}{\text { Rerata }}$ & $\begin{array}{l}\text { Persentase } \\
\text { Aspek }\end{array}$ \\
\hline & \multicolumn{2}{|l|}{ Penilaian dan Evaluasi } & $21.91 \%$ \\
\hline 1. & Menentukan prosedur penilaian & 3.74 & \\
\hline 2. & Mengadministrasikan penilaian proses dan hasil belajar & 3.72 & \\
\hline 3. & $\begin{array}{l}\text { Merancang alat evaluasi atau penilaian untuk mengukur } \\
\text { kemajuan dan keberhasilan pembelajaran }\end{array}$ & 3.56 & \\
\hline 4. & $\begin{array}{l}\text { Melakukan peniliaian dengan menggunakan tes dalam } \\
\text { bentuk teori dan praktikum }\end{array}$ & 4.10 & \\
\hline 5. & $\begin{array}{l}\text { Memanfaatkan hasil refleksi untuk perbaikan dan } \\
\text { pengembangan mata kuliah yang diampu }\end{array}$ & 3.49 & \\
\hline 6. & $\begin{array}{l}\text { Melakukan penilaian hasil pembelajaran menggunakan } \\
\text { standar penilaian dan panduan penilaian kurikulum kampus }\end{array}$ & 3.30 & \\
\hline
\end{tabular}

Melakukan penilaian dengan menggunakan tes dalam bentuk teori dan praktikum merupakan point tertinggi dengan rerata sebesar $4.10 \%$. Hal ini berarti dosen melakukan penilaian sesuai dengan ketentuan yang telah ditetapkan dalam evaluasi kurikulum dan pembelajaran. Sedangkan untuk persentase aspek penilaian dan evaluasi pembelajaran model block system learning sendiri memperoleh persentase sebesar $21.91 \%$. 


\section{d. Faktor pendukung dan penghambat model pembelajaran block system learning}

Dalam kegiatan pembelajaran sebagai pelaksanaan kurikulum pendidikan untuk memperoleh capaian tujuan pembelajaran tentu tidak selamanya berjalan dengan efektif. Ada beberapa faktor yang menjadi pendukung kegiatan tersebut, namun tidak dapat menutup kemungkinan dalam perjalan proses tersebut terdapat hambatan-hambatan dan kendala yang harus dihadapi.

Faktor pendukung dan penghambat dalam model pembelajaran block system learning dapat dilihat pada table dibawah ini:

Tabel 6. Hasil persentase angket kuesioner faktor pendukung dan penghambat pembelajaran

\begin{tabular}{|c|c|c|c|}
\hline \multirow{2}{*}{ No. } & Aspek-aspek & $\begin{array}{c}\text { Rerata } \\
\%\end{array}$ & $\begin{array}{l}\text { Persentase } \\
\text { Aspek }\end{array}$ \\
\hline & \multicolumn{2}{|l|}{ Faktor Pendukung dan Penghambat } & $22.07 \%$ \\
\hline 1 . & $\begin{array}{l}\text { RPS yang berjalan saat ini kurang mendukung pada komptensi } \\
\text { mahasiswa }\end{array}$ & 3.49 & \\
\hline 2. & $\begin{array}{l}\text { Mengalami kendala dan kesulitan pada saat pembelajaran di } \\
\text { kelas atau di laboratorium }\end{array}$ & 3.77 & \\
\hline 3. & $\begin{array}{l}\text { Mengalami gangguan pada fasilitas yang bersifat software } \\
\text { maupun hadware terhadap perencanaan, pelaksanaan, dan } \\
\text { evaluasi pembelajaran }\end{array}$ & 4.00 & \\
\hline 4. & $\begin{array}{l}\text { Institusi memberikan kebesan dalam pengembangan kurikulum } \\
\text { pembelajaran sesuai dengan KKNI dan SKKNI }\end{array}$ & 3.65 & \\
\hline 5. & $\begin{array}{l}\text { Sistem informasi akademik membantu kegiatan civitas } \\
\text { akademik dosen dan mahasiswa }\end{array}$ & 3.47 & \\
\hline 6. & $\begin{array}{l}\text { Melakukan umpan balik kepada mahasiswa sebagai penilaian } \\
\text { kinerja dosen }\end{array}$ & 3.74 & \\
\hline
\end{tabular}

Mengalami gangguan pada fasilitas yang bersifat software maupun hadware terhadap perencanaan, pelaksanaan, dan evaluasi pembelajaran memperoleh rerata tertinggi sebesar $4.00 \%$. Hal ini berarti masih terdapat kendala yang tinggi dalam pembelajaran menggunakan model block sytem learning. Sedangkan melakukan umpan balik kepada mahasiswa sebagai penilaian kinerja dosen memperoleh rerata sebesar $3.74 \%$.

\section{e. Dampak Model Pembelajaran block system learning}

Perubahan tingkah laku merupakan tujuan utama dari pembelajaran. Perubahan tersebut dapat kemampuan atau potensi yang harus dicapai dan dimiliki oleh setiap pembelajar. Memperoleh output bahkan outcome secara kuantitatif sering menjadi tolak ukur dalam pencapaian keberhasilan tujuan pembelajaran. Namun sejatinya dalam tujuan pendidikan nasional yang tercantum dalam UndangUndang No. 20 tahun 2003 tentang Sistem Pendidikan Nasional pasal 3 yaitu 
mengembangkan potensi peserta didik agar menjadi manusia yang beriman dan bertakwa kepada Tuhan Yang Maha Esa, berakhlak mulia, sehat, berilmu,cakap, kreatif, mandiri, dan menjadi warga negara yang demokratis serta bertanggung jawab.

Dengan demikian dampak model pembelajaran yang diperoleh dari hasil penelitian ini adalah sebagai berikut:

Tabel 7. Hasil persentase angket kuesioner dampak model pembelajaran

\begin{tabular}{|c|c|c|c|}
\hline \multirow{2}{*}{ No. } & Aspek-aspek & $\begin{array}{c}\text { Rerata } \\
\%\end{array}$ & $\begin{array}{l}\text { Persentase } \\
\text { Aspek }\end{array}$ \\
\hline & \multicolumn{2}{|l|}{ Dampak Model Pembelajaran } & $21.50 \%$ \\
\hline 1. & Penjadwalan waktu pembelajaran lebih singkat & 3.58 & \\
\hline 2. & $\begin{array}{l}\text { Mengajarkan materi pembelajaran sesuai dengan dengan } \\
\text { tujuan pembelajaran }\end{array}$ & 3.70 & \\
\hline 3. & $\begin{array}{l}\text { Dosen memberikan dorongan kepada mahasiswa selalu hadir } \\
\text { dalam pelaksanaan pembelajaran }\end{array}$ & 3.74 & \\
\hline 4. & $\begin{array}{l}\text { Memudahkan untuk menganalisa perilaku mahasiswa dalam } \\
\text { proses pembelajaran }\end{array}$ & 3.38 & \\
\hline 5. & $\begin{array}{l}\text { Menggunakan informasi hasil penilaian dan evaluasi untuk } \\
\text { menentukan ketuntasan pembelajaran }\end{array}$ & 3.27 & \\
\hline 6. & $\begin{array}{l}\text { Capaian kompetensi mahasiswa sesuai dengan kurikulum } \\
\text { PT yang berjalan }\end{array}$ & 3.83 & \\
\hline
\end{tabular}

Hasil presentase dampak model pembelajaran block system learning menunjukan bahwa dosen memberikan dorongan kepada mahasiswa untuk selalu hadir dalam pelaksanaan pembelajaran dengan rerata $3.74 \%$. Hal ini dimaksudkan agar mahasiswa tidak tertinggal materi yang disampaikan dalam pembelajaran karena tidak ada pengulangan atau review terhadap materi yang diberikan dan pada setiap pertemuan atau tatap muka berkanjut pada materi berikutnya. Capaian kompetensi mahasiswa sesuai dengan kurikulum PT yang berjalan memperoleh rerata sebesar $3.83 \%$. Hal ini diperkuat dengan adanya uji kompetensi mahasiswa sebagai alat ukur kompetensi mahasiswa sesuai dengan prodi masing-masing.

Dengan demikian gambaran hasil penelitian manajemen pembelajaran model block system learning ini dapat ditunjukan melalui grafik di bawah ini: 


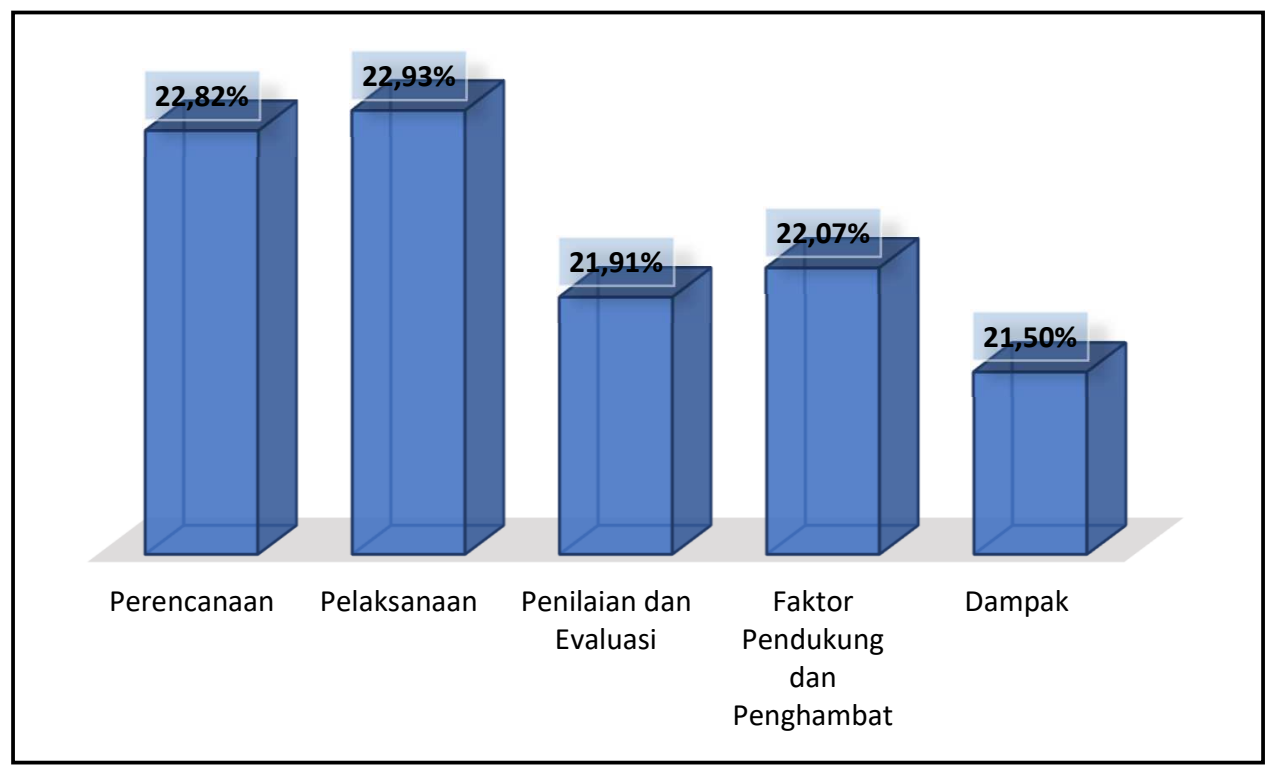

Gambar 7. grafik manajemen pembelajaran model block system learning

\section{Kesimpulan}

Manajemen pembelajaran model block system learning mempunyai lima unsur utama, yaitu 1) perencanaan. Pada aspek perencanaan berisi perancangan kebutuhan awal dalam pembelajaran dengan diawali FGD yang terdiri dari Wakil Direktur 1, Kabag Akademik, Prodi, dan Dosen merancang dan merumuskan silabus, RPS, modul, dan bahan ajar; 2) pelaksanaan meliputi kegiatan pembelajaran, pengembangan pembelajaran, dan iklim pembelajaran; 3) penilaian dan evaluasi meliputi pengadministrasian, prosedur penilaian, perancangan alat evaluasi, dan pemanfaatan hasil refleksi; 4) faktor pendukung dan penghambat menjelaskan tentang komponen-komponen pendukung dan penghambat dalam pembelajaran; 5) dampak yang diperoleh merupakan hasil dari pembelajaran dengan model block system learning.

\section{Daftar Pustaka}

[1] Sugiono. 2006. Metode Penelitian Kuantitatif, Kualitatif, dan R\&D. Bandung: Alfabeta

[2] Tim KPT. 2016. Panduan Penyusunan Kurikulum Pendidikan Tinggi. Kementrian Riset, Teknologi, dan Pendidikan Tinggi Direktorat jendral Pembelajaran dan kemahasiswaan Direktorat Pembelajaran RISTEK DIKTI 2016

[3] Tim KPT Belmawa HS. 2017. KKNI dan SN-DIKTI PERPRES 08/2012 \&PERMENRISTEKDIKTI 44/2015. RISTEKDIKTI: Tim Pengembang Kurikulum Pendidikan Tinggi Direktorat Pembelajaran-Ditjen Belmawa Kemenristekdikti

[4] Pemerintah Indonesia. 1999. Peraturan Pemerintah Nomor 60 Tahun 1999 tentang Pendidikan Tinggi. Lembaran RI tahun 1999 No. 60. https://kms.ipb.ac.id/1649/1/pdf

[5] Peraturan Menteri. 2015. Perarturan Menteri Riset, Teknologi, dan Pendidikan Tinggi Republik Indonesia Nomor 44 Tahun 2015 tentang Standar Nasional Pendidikan.Menteri Riset, Teknologi, dan Pendidikan Tinggi RI. 
https://img.akademik.ugm.ac.id/unduh/2015/PERMENRISTEKDIKTI_Nomor_44 Tahun_2015_SNPT.pdf

[6] Daulae, H, Tatta. (2014). Menciptakan Pembelajaran Yang Efektif. Forum Pedagogik Vo. 06, No. 02 Juli 2014. http://jurnal.iainpadangsidimpuan.ac.id/index.php/JP/article/download/181/163

[7] Ibrahim, \& Masitoh. (2011). Evaluasi Kurikulum. Jurnal Pendidikan Luar Biasa, FIP UPI. http://file.upi.edu/Direktori/FIP/JUR._PEND._LUAR_BIASA/196209061986011AHMAD_MULYADIPRANA/PDF/Evaluasi_Kurikulum.pdf

[8] Majid, A, D., Mukhadis, A., \& Poerwanto, E. (2011). Pengaruh Model Penjadwalan dan Motivasi Berprestasi Terhadap Hasil Belajar Perawatan Sepeda Motor Siswa SMK. Teknologi dan kejuruan Jurnal Teknologi, Kejuruan, dan Pengajarannya Universitas Negeri Malang Vol. 34 No.1 Pebruari 2011. http://journal.um.ac.id/index.php/teknologi-kejuruan/article/view/3020

[9] Rettig, D, Michael. (2018). Trends and Issues in High School Scheduling. Proffesor, Emeritus James Madison University. xPresident, School Scheduling Associates LLC Charlottesville, VA 22903 https://www.k12albemarle.org/acps/parents/8\%20period\%20hybrid/Trends_and_Is sues_in_High_School_Schedules.pdf

[10] Said, A., Benny, N., Hernawaty, D., \& Sondang, P. (2014). PKP Supervision Model Development Using the Block System Tutorial To Enhance The Teacher Professional Competence. PDE Professional Development in Education Confrence: Bandung, Park Hotel http://repository.ut.ac.id/4958/

[11] Jabar, A, S, Cepi. -. Human Instrument Dalam Penelitian Kualitatif: Sebuah Konsep.

http://staffnew.uny.ac.id/upload/132243758/penelitian/konsep+human+instrument .pdf 